\title{
Imágenes del rapto de la doncella en rituales festivos ibéricos
}

\author{
DEMETRIO E. BRISSET \\ Dpto. de Comunicación Audiovisual \\ Universidad de Málaga
}

\section{RESUMEN}

En las fiestas patronales de varios pueblos ibéricos, Luzbel convence a los "moros" para que se apoderen de la Virgen María. Este rapto ritual de la bella imagen de la mujer modélica en nuestra cultura se puede incluir dentro de un complejo simbólico expresado a lo largo de los siglos con muy variadas formas significantes; persistencia que indica su profunda implantación psíquica e influencia en las creencias y valores colectivos. Aquí se propone una aproximación comparativa etnohistórica, con el instrumental analítico de la antropología visual, para abordar el simbolismo de las diversas imágenes de la mujer raptada que aparecen en dichas representaciones festivas, tanto religiosas como profanas.

Palabras clave: Mitología, Leyendas, Fiestas, Antropología visual, Dragones y doncellas, España.

\section{SUMMARY}

During the patron saint's feasts in several small towns of the Iberian Peninsula, it is the devil who persuades the "moors" to kidnap the Virgin Mary. This ritual abduction of the model woman in Iberian culture can be regarded as part of a symbolic complex expressed throughout the centuries in various significant ways, the persistency of which indicating its deeprooted presence in hearts and minds and its influence on collective values and beliefs. Here I propose a comparative ethnohistorical approach, using the analytical tools of visual anthropology, to the symbolism of the different images of the abducted woman appearing in such patron saint's feasts, whether sacred or profane. spain.

Key words: Mythology, Legends, Feasts, Visual Anthropology, Dragons and Damsels,

RDTP, LVIII, 2 (2003): 201-222 
Ai de mim, fui desgraçada / ser dêste drago, Senhor!

Em andar a êle presa / A tantos anos de amor!

(Parlamento de la reina del baile dos turcos del Corpus de Penafiel, Portugal)

A pesar de los avances del feminismo durante el siglo XX, y especialmente desde 1968, en nuestros días todavía se constata la permanencia de instituciones raptoras, que permiten un dominio total de la mujer por parte del hombre ${ }^{1}$, incluyendo muchas uniones matrimoniales, donde se recluye y obliga a la esposa a trabajar al servicio del marido. Por otro lado, por la antropología sabemos que se produce una construcción simbólica de la realidad a partir de diversos mecanismos de transmisión cultural, y que los modos de comportamiento se interiorizan: no son innatos, sino adquiridos culturalmente.

Entre las diversas manifestaciones del dominio absoluto ejercido históricamente sobre la mujer, una de las más expresivas y extendidas representaciones icónicas es la que representa el rapto de la doncella por el dragón. Y tal como demostrara Wladimir Propp — del que en este ensayo utilizaremos ideas lamentablemente poco valoradas - esta acción resulta ser uno de los temas básicos de los cuentos maravillosos, de tan hondas raíces y tanta influencia sobre la educación infantil2 ${ }^{2}$. El aspecto físico de este raptor universal ha ido evolucionando, y en esa contemporánea mediación cultural que es el cine, en 1916 se transforma al dragón en una locomotora, a punto de atropellar a la heroína, salvada en el último instante por su enamorado, que llega a bordo de un automóvil. Y en 1933 se crea uno de los mitos fílmicos del siglo XX: el gorila gigante King-Kong, quien rapta a la joven de la que se enamora y es abatido por la aviación militar de los Estados Unidos.

En otro complejo cultural donde se entrelazan el teatro y la literatura oral, las luchas rituales entre dos bandos masculinos por la posesión de un bien colectivo (territorio, castillo, imagen patronal), que constituyen uno de los

\footnotetext{
${ }^{1}$ Actualmente, hay una serie de fenómenos sociales que manifiestan crudas formas de esclavitud femenina: las violaciones; los secuestros a manos de las soldadescas que pululan por tantos países en conflicto armado; las mafias de la prostitución que, mediante engaño y amenazas, atrapan en sus redes a jóvenes del Tercer Mundo o de las antiguas repúblicas socialistas para lucrarse con su alquiler en los burdeles occidentales; la compra de novias extranjeras por parte de los mozos chinos, que, debido a la política familiar dominante en su país (que privilegia el nacimiento de varones y elimina a muchas de las niñas recién nacidas), se encuentran sin mujeres solteras disponibles.

${ }^{2}$ Su Morfología del cuento fue publicada en ruso en 1928. La marginación de este precursor del estructuralismo pudo deberse a las críticas - no muy fundadas - a las que le sometió Lévi-Strauss, aunque hoy día se le está redescubriendo, especialmente por su metodología analítica de los relatos.
} 


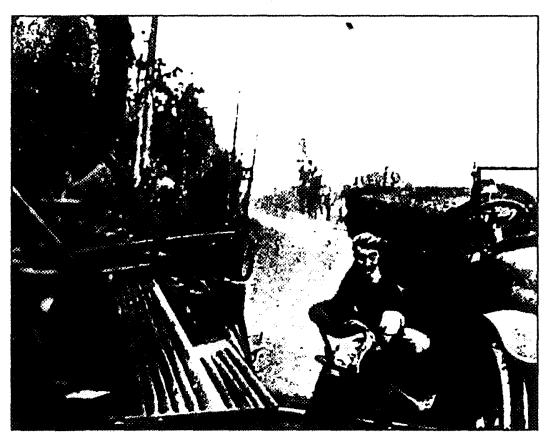

FigurA 1.-Desde bastante pronto, el cinematógrafo transformó las historias de damas raptadas adaptándolas a las nuevas tecnologías, como en este filme de 1916.

evolución va en el sentido de disminuir el ingrediente religioso ante la presión del componente lúdico, todavía se cuentan dieciséis localidades hispanas en las que el bando de los enemigos - los moros- cautiva la escultura de la Virgen María o de una santa $^{3}$. Estas imágenes pudieran ser alegorías de doncellas, como manifiestan algunos parlamentos declamados por el bando enemigo, como en la alpujarreña Albondón, donde el Sultán amenaza con que: “iLlenaré mis harenes, con las vírgenes cristianas!.’. Parecida equiparación ya se le ocurrió a Don Quijote, cuando acometió contra la procesión de disciplinantes que portaba "la imagen benditísima de la Virgen", para liberar a "aquella festejos tradicionales más característicos de la cultura hispánica, y que ya estudiamos en otra ocasión (Brisset 1997), de modo bastante sorprendente también resulta ser uno de sus temas básicos. Estas representaciones rituales hispánicas de conquista, especialmente en su variante de "lucha entre moros y cristianos", siguen siendo muy populares en cientos de pueblos, que las llevan a cabo como acto semilitúrgico en honor de sus patronos tutelares. Aunque su reciente

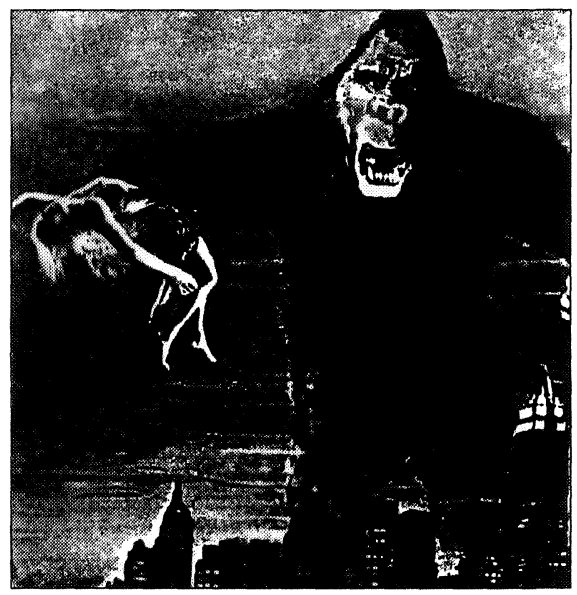

FIGURA 2.-El gigantesco gorila KingKong, protagonista de la película de Merian Cooper y Ernest B. Schoedsack, basada en una novela de Edgar Wallace y producida por RKO en 1933, inició una saga fílmica de monstruos emparentados con los dragones.

${ }^{3}$ En las fiestas donde los moros pretenden apoderarse de la dama, se trata de la Virgen María (bajo diversas advocaciones) en: Atalbéitar, Picena y Montejícar (Granada); Campillo de Arenas y Carchelejo (Jaén); Puebla de Alfarnate (Málaga); Casas Ibáñez y Jorquera (La Mancha); Alcalá de la Selva e Hijar (Teruel); Mas del Olmo y Tuéjar (Valencia); mientras que se trata de las santas Ana (en la granadina Molvízar), Águeda (Escatrón) y Bárbara (Fuentes de Ebro), ambas localidades zaragozanas, y Catalina (en la valenciana Aras). 


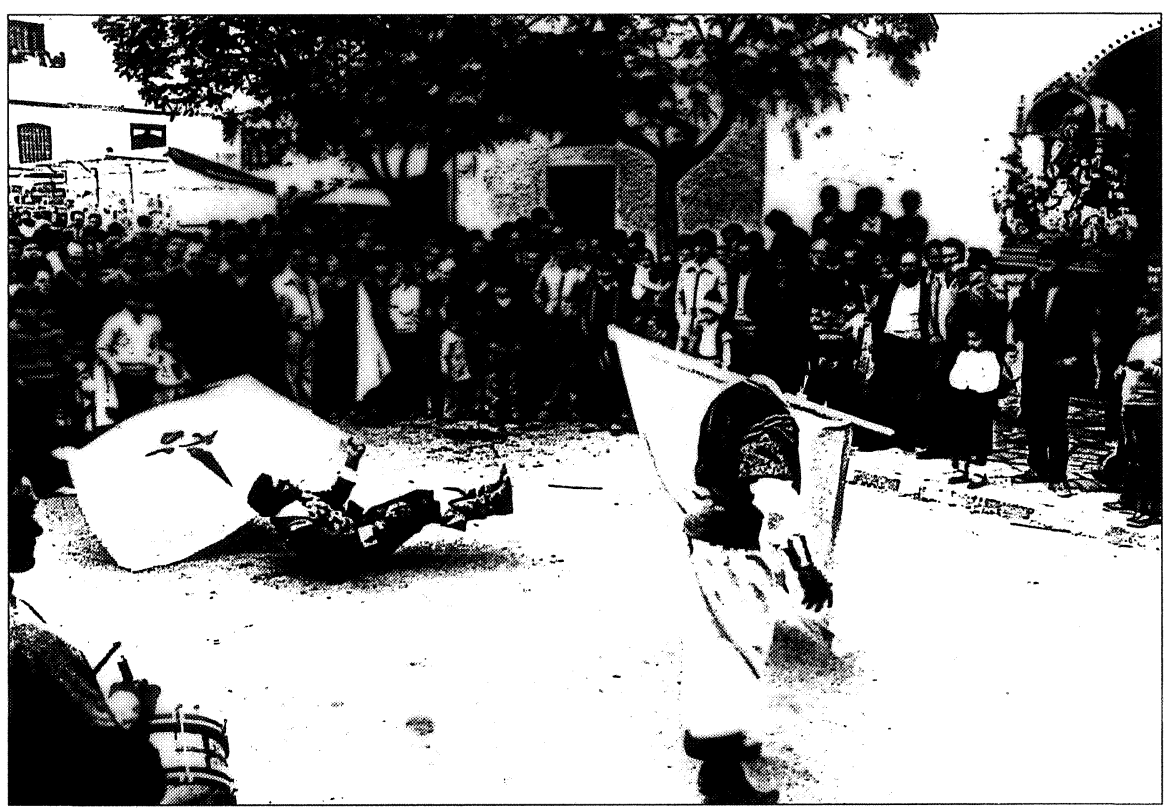

Figura 3.- "Juego de las banderas" en la función de Moros y Cristianos de la granadina Zújar, ante la imagen de la Virgen de la Cabeza, raptada por el bando moro.

buena señora que allí va cautivan, cumpliendo así con su deber de caballero andante de ayudar a las damas en desgracia ${ }^{4}$.

Por nuestra parte, para tratar ahora de interpretar este complejo simbólico, comenzaremos por aislar las influencias festivas que han intervenido en la incorporación del rapto de la doncella a este conjunto de rituales.

\section{GÉNESIS FESTIVA}

Las representaciones rituales de conquista constituyen un universo festivo de compleja evolución. Desde el siglo XII, el fingido combate entre Moros y Cristianos coexistió con el de otros bandos enfrentados. Aquí nos limitaremos a documentar variantes de luchas por doncellas:

- 1373, Valencia, en la boda del infante D. Juan de Aragón con D $\mathrm{D}^{\mathrm{a}}$ Juana de Francia, un juego organizado por los freneros: un dragón humeante escoltado por hombres salvajes impedía a la comitiva de la novia

\footnotetext{
${ }^{4}$ Con esta rara aventura concluye la I Parte del Quijote (cap. LII).
} 
cruzar un puente, saliendo varios jinetes a combatir para dejar el paso libre (Carreres 1925: 36).

- 1424, Barcelona, recibimiento a Alfonso V en su regreso de Nápoles, con la procesión del Corpus Christi, que incluía entre los entremeses municipales a san Jorge a caballo, la víbora o dragón y el carro con la doncella (Amades 1966: 98).

- 1538, Valencia, fiesta en el palacio de la ex-reina de Aragón: representación del rescate por los Caballeros de San Juan de sus amadas damas, que habían sido cautivadas por piratas turcos (corteses, éstos a su vez se enamoraron y trataron bien a las damas, por lo que fueron perdonados) (Milán 1561).

- 1549, Binche, fiestas en honor de príncipe Felipe, heredero de Carlos I: un día, los caballeros lucharon para rescatar a la reina encantada, prisionera en el Castillo Tenebroso, consiguiendo la hazaña el propio Felipe; otro día, en el salón de baile irrumpió una tropa de salvajes que raptó a varias damas llevándolas a una fortaleza cercana, adonde acudió la corte en romería para rescatarlas (Devoto 1960).

- 1570, Burgos, recibimiento a $\mathrm{D}^{\underline{a}}$ Ana de Austria, en ruta para los desposorios con Felipe II: en la plaza mayor se representó parte del Amadís de Gaula, incluyendo el rapto de la infanta Oriana (Relación verdadera 1571).

- 1571, Lorca (Murcia), alegrías públicas por el nacimiento del príncipe Fernando de Austria. El historiador-novelista Ginés Pérez de Hita organizó unas invenciones con tomas de castillos, entre las que se incluía el rapto de una bella doncella por un "caballero bravo y fuerte" que, con furor, "lanzaba por la boca y ojos fuego", quien la recluye en un castillo custodiado por doce "salvajes fieros", para ser luego liberada por su amado, un caballero al servicio de la diosa Venus (Pérez de Hita 1572).

- 1609, Valencia, fiestas por la beatificación de san Luis Beltrán: liberación de la dama encantada, secuestrada por fieros animales en un castillo (Alenda 1903: 149).

\footnotetext{
${ }^{5}$ La relación de estos festejos ocupa los tres últimos cantos de su historia de Lorca, escrita en octavas reales por encargo del concejo y que nunca llegaría a editarse. En la Biblioteca Nacional de Madrid se conserva una copia manuscrita del siglo XVIII, que fue comentada por Joaquín Espín Rael en su estudio de 1922 sobre el escritor y zapatero murciano, quien ganó los 6.000 maravedíes que la ciudad concedía "al que mejor invención sacare. En los otros juegos se representaba a un rey preso y encantado por un "jayán descomunal" ayudado por "un mágico", y el cautiverio de caballeros cristianos por los moros, que, vencidos luego, son atados y paseados.
} 
- 1609, en un pueblo de Levante, danza de cascabel del Corpus que representa el rescate de Melisendra - hija de Carlomagno- por su esposo Don Gayferos, de la torre del alcázar de Zaragoza, donde el rey musulmán Marsilio hacía años que la mantenía prisionera (Pérez Pastor 1911: CLXXIV). Justo por entonces estaría Cervantes redactando la aventura de maese Pedro el titiritero, que muestra a Don Quijote ayudando con su espada a la liberación de la princesa cautiva, con el destrozo de los títeres (II, cap. XXVI).

- 1651, México, fiesta de la Purísima Concepción a cargo de la Universidad, con la representación de una comedia basada en el rapto de Helena, con la quema del carro que simbolizaba la ciudad de Troya (Warman 1985: 88).

Dejaremos aquí esta relación de festejos singulares, para entrar en la literatura oral y la teatral. En la Península Ibérica, el tema de la cristiana cautiva tuvo durante siglos gran popularidad en el romancero. En él destaca la triste historia de Blancaflor, raptada el día de Pascua Florida mientras iba de romería a Santiago con su esposo, el conde Flores; ella estaba cortando rosas cuando les sorprendió el ataque de los moros, que mataron al conde. El romancero del norte del Duero recoge buen número de dramas parecidos, hasta tal punto que se pueden agrupar en un ciclo de la cristiana cautiva, con diferentes desarrollos: en unos reniega; en otros convierte a la morilla con quien convive; y en alguno se deja arrastrar por su ambición y se dedica a buscar el poder (Chaves 1948).

En nuestro Siglo de Oro, los corrales de comedias quizás eran la diversión pública más popular. Muchas obras se inspiraban en el romancero, teniendo gran aceptación las que trataban sobre duelos entre moros y cristianos, con doncellas rescatadas y bodas finales, hasta el punto de que muchos autores eclesiásticos las incluyeron en su repertorio. Sin acumular ejemplos, veamos sólo algunos significativos:

En La toma de Sevilla por el santo rey Fernando, de Christóbal de Morales, la ciudad se representa como una dama cautivada, igual que se hace con Málaga en $N^{a} S^{a}$ de la Victoria y restauración de Málaga, escrita por Francisco de Leyba hacia 1673. En Origen de $N^{a} S^{\underline{a}}$ de las Angustias y revelión de moriscos, del sacerdote Fajardo y Acevedo, impresa en 1675, el capitán general de Granada libera a la dama $\mathrm{D}^{\mathrm{a}}$ María de Solís, cautiva de los moriscos rebeldes. Y en la Comedia de la Soberana Virgen de Guadalupe, impresa en 1615 y atribuida a Cervantes, la esposa del alcaide cristiano de Sevilla es capturada por el general moro, que se enamora de ella, prefiriendo el alcaide huir con la imagen de la Virgen para ponerla a salvo, antes que rescatar a su propia mujer. 
Pero hay un tema teatral del mayor interés para nuestro estudio, por lo que merece la pena detenerse en él. Antes de 1618, Lope de Vega recrea el legendario "tributo de las cien doncellas" que el rey musulmán de Córdoba exigía al cristiano de León, en su comedia Las famosas asturianas ${ }^{6}$ (1974), que, parece, se inspiraba en un poema de Pedro de la Vezilla, impreso en Salamanca en 1586. Avanzado el siglo XVII, otro gran autor teatral, Álvaro Cubillo de Aragón, en El rayo de Andalucía y genizaro de España, fusiona dicha leyenda con la de los Siete infantes de Lara, venciendo los leoneses en Clavijo, gracias a Santiago y al grito de “Viva la libertad, y muera el trato/ que introduxo el infame Mauregato!n?

Este tributo también es un arraigado tema folklórico, que aún se recuerda ritualmente por el norte de España, tanto en León capital con sus cantaderas y en la riojana Sorzano con su procesión de las doncellas que portan ramos de acebo a la ermita de la Virgen del Roble, como en la soriana San Pedro Manrique, con sus mozas o móndidas del solsticio de verano, que salen del pueblo cargadas de ofrendas "a esperar a los moros". En este caso, Caro Baroja demostró que tales personajes "descienden de las doncellas que llevaban cistas [cestas con ofrendas] o que hacían un sacrificio rústico" en los cultos agrícolas mistéricos de la Antigüedad clásica, como los de Dionysos y Deméter en Grecia, y de Baco y Ceres en Roma (Caro Baroja 1974: 63), lo que se puede extender al caso riojano, mientras que la leonesa danza de las ocho cantaderas, dirigidas por otra mujer vestida como mora, la sotadera, es un enigma simbólico.

Lo significativo es que popularmente se relacionan estos grupos de jóvenes solteras con el antiguo tributo. Sin embargo, no se ha encontrado evidencia documental del famoso "tratado de Mauregato", por el cual los hispano-visigodo-romanos debían entregar anualmente una paria que se materializaba en tales doncellas. Como motivos inspiradores de esta leyenda podrían encontrarse uno histórico y otro mítico. Según fuentes musulmanas del siglo XIII, la rápida conquista de Hispania en el 712 les proporcionó fabulosas riquezas: el caudillo Musa Ibn Nusayr, tras la victoria, «llamado por el Califa, regresa a Siria con un gran botín y 30.000 vírgenes [hijas de la nobleza]" (Ibnel-Athir 1896: 47). En cuanto al otro modelo, se podría rastrear en el mito griego de Teseo, vencedor del Minotauro cretense para liberar a los atenienses de su tributo de siete doncellas y siete mancebos. Hemos llegado al territorio mítico, conectado con los ritos, religiones, cuentos y folklore. Dentro de él vamos a centrarnos en el tema del rapto de la doncella y sus conexiones.

\footnotetext{
${ }^{6}$ Escrita según el mismo Lope aen lenguaje antiguo para dar mayor propiedad a la verdad del asunton.

7 Impresa en Salamanca en 1792.
} 
El rapto simbólico de las doncellas que aparece en muchas de nuestras expresiones culturales, puede remontar su procedencia a varias de nuestras más antiguas creencias. Busquemos el material comparativo, sincro-diacrónico, que nos permita establecer la evolución histórica de las diversas variantes de lo que podemos considerar trama argumental, para conocer las condiciones que la han hecho posible y sugerir una explicación. Para ello, enfocaremos el fenómeno de la mujer raptada desde sus diversos aspectos, de acuerdo con la metodología comparativa morfo-histórico-cultural diseñada por el maestro Julio Caro Baroja.

- Histórico: El llamado "padre de la historia", Heródoto de Halicarnaso, comienza su Libro I exponiendo el objetivo que le lleva a escribir: "Para que no se desvanezcan con el tiempo los hechos de los hombres [...] y, sobre todo, la causa por la que se hicieron guerra [griegos y bárbaros], y al investigar tal causa, encuentra que fue el rapto de mujeres. Primero, los fenicios raptaron en Argos a Io, la hija del rey. Los cretenses devolvieron la fechoría cautivando a Europa en Tiro. El siguiente agravio fue otra vez griego, raptando en la Cólquide a Medea, también hija de rey. Dos generaciones después, Alejandro, hijo de Príamo, "quiso tener mujer raptada de Grecia, seguro de que no había de dar satisfacción, pues tampoco la habían dado aquellos. En efecto, cuando robó a Helena, los griegos acordaron enviar primero embajadores para reclamarlan, y al no obtener respuesta a su petición, juntaron gran ejército "pasaron el Asia y destruyeron el reino de Príamo" (Heródoto 1983: 11-13). Se aprecia que el rapto de mujeres estaba considerado en el siglo $\mathrm{V}$ a.C. como el motor de la historia, al desencadenar guerras. $\mathrm{Y}$ no hay duda de que es una de las motivaciones que impulsan a invadir otros territorios: robar alimentos, ganado, mujeres y hacer esclavos. Por otro lado, en las leyendas griegas y romanas abundan los casos de mujeres raptadas, tanto por dioses (que pueden adoptar figura humana o animal) como por semihumanos.

- Mítico-religioso: Esta realidad histórica coincidió con diversas formas de representar los entonces inexplicables fenómenos naturales. Tanto la religión como los mitos y los cuentos cumplen similar tarea de ofrecer un modelo del mundo, de transmitir una cultura, por lo que vamos a tratarlos con la misma intensidad. Es universal el temor a los espíritus de los difuntos, pues se les atribuían la enfermedad, los dolores y la muerte. Al simbolizar la fatídica muerte fue imaginada como una fiera devoradora, que raptaba la vida. Con el desarrollo de las ideas religiosas, el animal se fue sustituyendo por el dios, que conserva su zoomorfismo. Más adelante, se humanizará. Como dice Propp: 


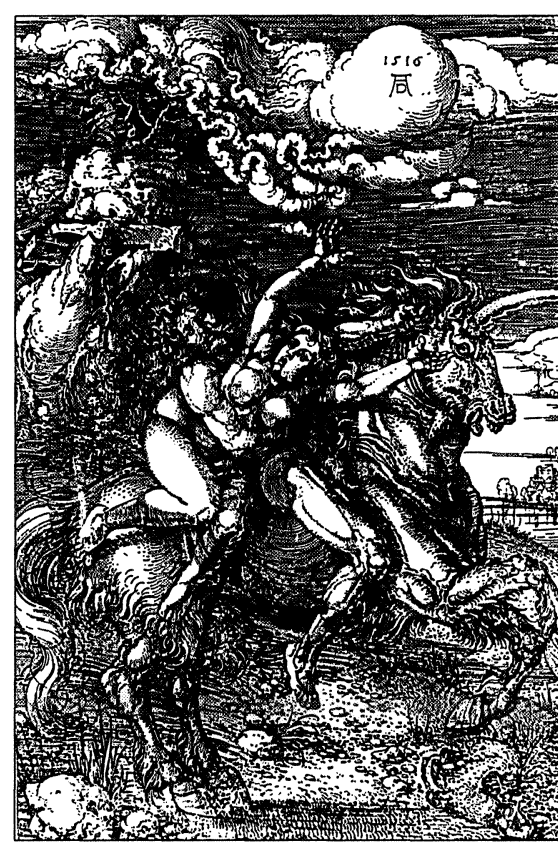

FIGURA 4.-Rapto de Proserpina. Grabado de Durero, 1516.

"En los primeros tiempos, el hambre del alimento es primordial: la muerte devoradora es más antigua que los restantes tipos de muerte [...] Con el progreso de la evolución social, pasa a primer plano la satisfacción del sentimiento sexual, y este erotismo se inserta en las representaciones religiosas preexistentes, y en especial en la muerte como rapto. La divinidad escoge a un novio o novia entre los mortales, y se lo lleva al reino de los muertos para desposarlo" (1974: 369-371).

Propp añade que hay toda una serie de mitos o leyendas de antiguos pueblos primitivos acerca de secuestros de seres humanos, llevados a cabo por uno u otro animal. Y que la narración maravillosa es más arcaica que los mitos religiosos tardíos con su divinidad raptora: en los cuentos, el raptor conserva su naturaleza de animal devorador, que en los mitos casi se ha perdido. $\mathrm{Y}$ en ambos universos simbólicos encontramos como gran raptor la figura del dragón.

La etnografía contemporánea nos documenta diversas variantes de raptores, de las que me limitaré a seleccionar algunas significativas:

1) En los Pirineos, hasta el siglo $\mathrm{XX}$, en las mascaradas invernales se hacían representaciones mímicas con rapto incluido. En el Soule vasco-francés, las funciones comenzaban con el rapto de un Cordero por el Oso, la persecución por parte del Pastor ayudado por los Gitanos, el combate y la muerte final del oso (en otra variante, del cordero) (Hérelle 1923: 173). Al sur, en el Vallespir, el "Oso de la montaña" es encadenado por los cazadores, pero se escapa de su domador y se apodera de la moza "Rosetta", con la que se encierra en la cabaña levantada en la plaza, que simula ser su cueva, siendo atacado y muerto para resucitar a continuación y perseguir libidinosamente a las mozas (Van Gennep 1947: 1-III, 909).

2) En la portuguesa Penafiel, hasta 1930, en la fiesta del Corpus se escenificaba el rapto de la dama cristiana por un dragón y sus aliados turcos, siendo finalmente liberada por san Jorge. 
3) En el barrio del castillo de Cuenca, en su fiesta patronal de primavera, hasta 1975, se representó una función teatral de tema carolingio, donde la reina mora "Floripes" terminaba cautiva de los cristianos.

4) En muchos rituales festivos del Corpus Christi ibérico siguen saliendo a las calles las figuras del dragón y la doncella, llamada tarasca en Granada y anabolena en Toledo.

De las diversas formas de raptores de doncellas, creo que simbólicamente la más interesante es la tenebrosa figura del dragón.

\section{LOS TERRIBLES DRAGONES}

Se puede aceptar que desde los comienzos de la humanidad ha estado presente el terror mental a diversos tipos de figuras monstruosas, conectadas con la muerte, las profundidades y el agua. En los mitos religiosos, con carácter universal se encuentra un temible monstruo, tipo sierpe o dragón (del griego drakon: serpiente; de ahí el latín draco, término que aún utiliza Berceo para la fiera, símbolo del mal), que posee naturaleza acuática y puede entroncarse con la fecundidad. Sus ejemplos reales deben ser los cocodrilos, serpientes y ciertos lagartos gigantes, como el animal que hoy día vive en el Pacífico, denominado dragón de Komodo (isla al este de Bali), que alcanza tres metros de longitud y está relacionado con otro de mayor tamaño que existió en China. Quizás esta especie de gran saurio chino ayudase a la relevancia de esta figura simbólica, venerada como dios de la lluvia, en sus rituales festivos, que pudieron servir de modelo procesional para otros pueblos.

En su aspecto icónico, los terroríficos dragones alados parecen tener su inspiración plástica en los bajorrelieves babilónicos, posiblemente a partir de la sierpe cornuda que hacia el 2100 a.C. se esculpía en el reino de Gudea (Mesopotamia) ${ }^{8}$, pasando esta figura a convertirse en emblema de Marduk. En la Puerta de Ishtar de Babilonia se representa al poderoso dios Marduk como un dragón o animal, compuesto con elementos de víbora, águila, león y escorpión, destacando su carácter mortífero, para asustar a los enemigos, la misma función que luego cumplirían los genios alados o demonios asirios. Otra línea genética se podría rastrear en el Antiguo Egipto, cuando se creía que un monstruo-cocodrilo devoraba a los muertos no absueltos por el tribunal de Osiris9. En la India, al dragón se le llamaba Varuna, y era dios del orden, la ley y la muerte, y señor de las aguas, asociado con la virilidad, los

\footnotetext{
${ }^{8}$ En estelas conservadas en el Museo del Louvre.

9 Se conservan tales imágenes en el Libro de los Muertos, por lo menos desde 1500 a.C. (Museo del Louvre).
} 
tesoros y animales acuáticos como serpientes y lagartos. Carácter parecido tiene en China, donde consta de "cuernos de ciervo, cabeza de camello, ojos de demonio, cuello de serpiente, vientre de almeja, escamas de carpa, garras de águila, patas de tigre y orejas de vaca. También debía tener un gran bulto en la parte superior de la cabeza, gracias al cual podía volar" (Huxley 1994: 87). En Oriente se tenía una visión favorable de los dragones, y se cuenta de un descendiente del emperador chino Yao, que aprendió a criarlos en su palacio.

En la Hispania visigoda, san Isidoro de León en sus Etimologías estableció una clasificación de la especie biológica de los dragones, según sus atributos anatómicos y poderes maléficos, diferenciándolos en "sierpes, hydras, basiliscos, grifos...”, y describe así al draco:

es la mayor de todas las serpientes y de todos los animales de la tierra [...] saliendo de su cueva se remonta por los aires y hace que se produzcan ciclones. Es animal con cresta, boca pequeña, conductos estrechos por los cuales respira y saca la lengua. Su fuerza no está en los dientes, sino en su cola [...] No tiene veneno porque no le es necesario para causar la muerte [...] Se cría en Etiopía y en la India en medio de los grandes calores (Isidoro 1951: 297) ${ }^{10}$.

Horrorosas bestias de esta estirpe aparecen profusamente esculpidas en los capiteles de nuestros templos románicos. Como muestra de su difusión iconográfica se pueden mencionar las merindades burgalesas, donde los grifos o leones alados pasan de ser motivo simbólico en ermitas y monasterios a las fortalezas, como se evidencia en el castillo de Frías.

En palabras de Propp:

el combate contra la Sierpe en forma evolucionada se encuentra en todas las antiguas religiones estatales: en Egipto, Babilonia, en la antigüedad clásica, en la India, en China; ha pasado también al cristianismo [...] Pero el motivo del duelo con la serpiente no existe en los pueblos que aún no han formado un estado (Propp 1974: 328).

En el Antiguo Egipto se representaba icónicamente la muerte del dragón Apofis con una lanza que esgrime Set a bordo del barco solar de Horus. En Grecia, Herakles derrota a Ladón, que vigilaba el manzano del Jardín de las Hespérides; Perseo degüella a la Gorgona, protegido con el yelmo de la invisibilidad, y luego rescata y desposa a la bella Andrómeda, que había sido encadenada a las rocas para que la devorase un monstruo marino de sexo

${ }^{10}$ En el capítulo IV, "Serpientes", del Libro XII "De los animales" de sus Etimologias, tratado que pretende agrupar los conocimientos de la época. Ya las sierpes se representan en insculturas castreñas galaicas. 
femenino que estaba arrasando el país ${ }^{11}$; el dragón "que mató Cadmo, antepasado de Edipo, tiene [gran] significado genealógico [puesto que] en tiempos de Pausanias aún se localizaba dónde había ocurrido la muerte del dragón y la siembra de los dientes de éste por Cadmo. La historia se halla relatada en muchos sitios, con variantes", por ejemplo, en Eurípides y Apolodoro (Caro Baroja 1974: 206).

Desde sus inicios, la religión judía manifestó el temor hacia estos monstruos, al creer que la serpiente bíblica engañó a Eva, y a través suya, a Adán. En el Apocalipsis cristiano, san Juan narra la visión de una Mujer encinta, coronada de estrellas y con la luna bajo sus pies, ante la que surgió "un dragón color de fuego, con siete cabezas y diez cuernos, y su cola arrastraba la tercera parte de las estrellas", con la intención de devorar al hijo en cuanto naciera. Para evitarlo, llegaron Miguel y sus ángeles que lucharon y vencieron: "y fue precipitado el gran dragón, la serpiente antigua, que se llama Diablo y Satanás, el seductor del mundo entero" (Apocalipsis: XII, 9). Pronto se atribuyeron victorias contra dragones reales a santos como el papa san Silvestre (para satisfacer una petición del recién converso Constantino) y el obispo san Donato, quien mató al dragón que envenenaba las fuentes de Epiro, lanzándole un escupitajo a la cara. Luego, la nómina de los santos dragonicidas se fue ampliando con Demetrio, Jorge, Bernardo, Marcelo...

En España también se cuenta con un caso en la Edad Media: el piadoso pero no canonizado caballero navarro don Teodosio de Goñi, haciendo penitencia solitaria en el monte Aralar (cerca de Lecumberri), se acercó a una cueva donde solía habitar un gran dragón, quien al percibirlo "erguido su erizado cuello, centelleando sus ojos, fulminando estragos entre horribles silvos, abierta la ponzoñosa boca y vibrando el arpón mortífero de su lengua, le acometió con impetuosa furia para hacerle presa de sus uñas, cebo de sus dientes y pábulo de su voraz estómago insaciable", pero al invocar al arcángel Miguel, éste apareció para vencer al maligno, como narra el capuchino navarro fray Tomás de Burgui (1774: 39), al escribir la historia del santuario de San Miguel de Aralar, fundado por el agradecido don Teodosio, y donde recibió sepultura. Todavía en 1919, Barandiarán recogió de la tradición oral en Ataun, que don Teodosio había decidido entregarse en lugar de la doncella que debía ser devorada por el dragón que habitaba la cueva del Aralar, como parte del tributo diario de una víctima humana, y cuando estaba a punto de ser tragado por el monstruo (iraunsugue en vasco, que puede corresponder a "serpiente antigua") fue salvado por san Miguel. Esta serie de le-

${ }^{11}$ Es curioso el cuadro pintado por Joachim Wtewael en Utrech en 1630, "Perseo socorre a Andrómeda", donde el héroe desciende del cielo en un caballo alado blandiendo una espada para luchar contra el dragón marino. 


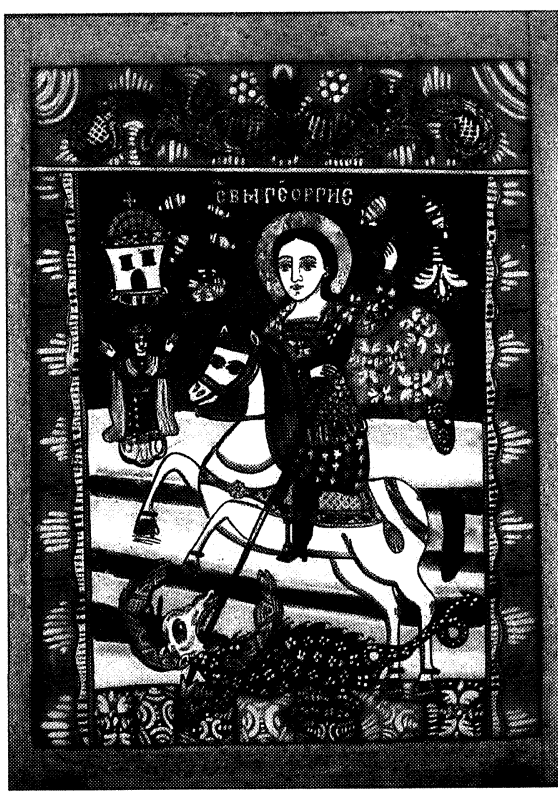

FIGURA 5.-San Jorge atravesando al dragón. Pintura sobre vidrio. Yugoslavia. Musée de L'Homme de París. yendas han sido objeto de estudio por un descendiente de don Teodosio, como era Julio Caro Baroja, "no con ánimo de demoler una tradición piadosa [sino] con el de resaltar, precisamente, lo que tiene de vital y sugestiva para los hombres" (1974: 182). Otra curiosa tradición se mantiene en la montaña leonesa, cuando los vecinos de La Vid suben a la ermita de san Lorenzo el día de su fiesta para agradecerle que les hubiera liberado de una voraz serpiente o culebro que dominaba el desfiladero, y dentro del humilde templo encienden velas al pie "de una estela dedicada a los dioses Equeunuros, posible divinidad indígena astur" (López 1999: 43).

De entre los héroes vencedores de dragones, el más conocido actual-

mente es san Jorge. Su iconografía canónica lo muestra como un joven con un arma metálica (lanza, espada) a caballo, compartiendo la escena con el monstruo al que ataca y la doncella a la que salva. A veces se incluye un cuarto elemento: en un altar de Valencia, de 1410-20, aparece una mano que surge de un agujero celeste para manifestar su apoyo al caballero. En un cuadro de Tintoretto, de 1560, es Dios Padre, quien desde una nube bendice a su protegido. Es destacable su semejanza icónica con la ilustre pareja en combate constituida por el arcángel san Miguel y Satanás. La etimología latina de su nombre lo conecta con agricultor. Según el relato de su vida en la medieval Leyenda Áurea, fue un tribuno oriundo de Capadocia. En cierta ocasión llegó a una ciudad llamada Silca, en

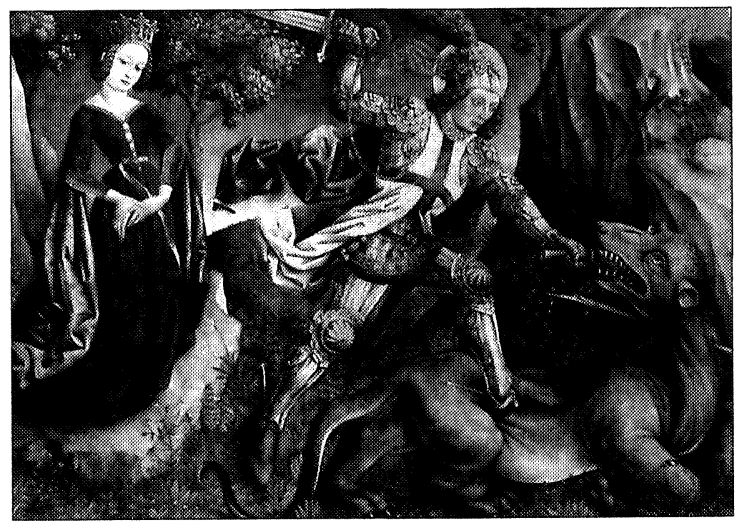

Figura 6.-San Jorge y el dragón. Escuela del Alto Rhin, siglo XV. Musée d'Unterlinden, Colmar. 
Libia; cerca de la población había un lago tan grande que parecía un mar, y en él

se ocultaba un dragón de tal fiereza y tan descomunal tamaño, que tenía amedrentadas a las gentes de la comarca [y] era tan sumamente pestífero, que el hedor que despedía llegaba hasta los muros de la ciudad, y con él infestaba a cuantos trataban de acercarse a la orilla. Los habitantes de Silca arrojaban al lago cada día dos ovejas para que el dragón comiese y los dejase tranquilos [pero] al cabo de cierto tiempo quedáronse con un número muy escaso de ovejas [por lo que] acordaron arrojar cada día al agua, para comida de la bestia, una sola oveja y a una persona, designada mediante sorteo. Así se hizo, pero llegó un momento en que casi todos los habitantes habían sido devorados por el dragón [y] la suerte recayó en la hija única del rey [...].

El rey propuso donar sus riquezas si se la excluía, pero el pueblo se negó. Vestida con suntuosas galas, la joven se dirigió llorando hacia el lago, cuando se encontró con san Jorge, quien se propuso ayudarla. Al salir del agua el dragón, el santo espoleó a su caballo y le embistió con la lanza, hiriéndole. A continuación dijo a la joven que se quitara el cinturón y sujetara con él al monstruo por el pescuezo, y se dirigieron a la ciudad seguidos por el dragón como si fuera un perrillo. Asustados los vecinos al verlos, el santo les propuso matar la bestia si se bautizaban, y al hacerlo así, "desenvainó su espada y con ella dio muerte al dragón". El rey, agradecido, hizo construir una gran iglesia dedicada a santa María y san Jorge, surgiendo al pie del altar una fuente de aguas milagrosas. El santo no aceptó la fortuna que le ofrecían, y se marchó del lugar. Predicando contra los dioses paganos, fue encarcelado y torturado, sin sufrir daños:

Presa de inmenso furor, el juez mandó que frieran al santo en una descomunal sartén llena de plomo derretido. Entró Jorge en la sartén haciendo la señal de la Cruz, tendíose en ella y se sintió tan a gusto como si estuviese tomando un baño delicioso.

Terminó siendo decapitado hacia el año 287 de nuestra era. Siglos después, cuando las tropas cristianas sitiaban Jerusalén:

el santo se les apareció, vestido de blanco, perfectamente armado y enarbolando a modo de estandarte una cruz roja, y con enardecidas palabras les animó a que le siguieran [y] los soldados cristianos treparon hasta las almenas, conquistaron la ciudad de Jerusalén y dieron muerte a los sarracenos que la ocupaban (De la Vorágine 1982: I, 248-253).

En Europa, este santo se convirtió en prototipo del caballero bajo-medieval, reemplazando como patrono de la caballería a san Martín, obispo de Tours, al que se representa montado a caballo, dividiendo su capa con un pobre. Esta sustitución puede ser consecuencia de las relaciones con el Oriente, 
promovidas por las cruzadas. Muy venerado en el Norte de Europa, san Jorge fue adoptado como patrono por los ingleses, a quienes apoyó contra Francia durante la Guerra de los Cien Años, y todavía en la I Guerra Mundial un soldado británico le vio atacar a los alemanes en la batalla del Marne (Gabet 1989: 35).

San Jorge también es patrono de Portugal y del antiguo reino de Aragón. Conocido como san Jordi en Cataluña, en su día es costumbre regalar rosas y libros. En la localidad leonesa de San Esteban de Nogales sacan en procesión su busto-relicario, con la posterior representación escénica y pirotécnica de la obra San Jorge y el dragón. En Cáceres agradecen su patrocinio bélico, porque en su día las tropas cristianas tomaron la ciudad, hecho que se recuerda con Moros y Cristianos, desfile de dragones y batalla de san Jorge con el dragón, que es vencido y quemado. Y en la alicantina Alcoy tiene lugar en su honor una de las fiestas de Moros y Cristianos más concurridas de España, con múltiples filáes o compañías en ambos bandos, alardo o batalla de arcabucería y embajadas con emotivos retos. Un niño, montado sobre un caballo blanco de cartón, representa a San Jordiet, que aparece tras las almenas del castillo para otorgar la victoria a los cristianos. El hecho que se conmemora es su aparición, en 1276, a las tropas de Jaime I el Conquistador, que defendían la villa ante un cerco musulmán. Ya en 1668 consta este tipo de fiesta a cargo de la soldadesca; desde entonces apenas ha variado, hasta que en 1997 se integra la primera mujer en una de las veintiocho filáes.

Volviendo al dragón, un hecho que se repite en varias civilizaciones - $\mathrm{y}$ como antes se ha visto, recoge la leyenda navarra- es la necesidad de ofrecerle sacrificios humanos a fin de mantenerle calmado. En el Punjab, en épo-

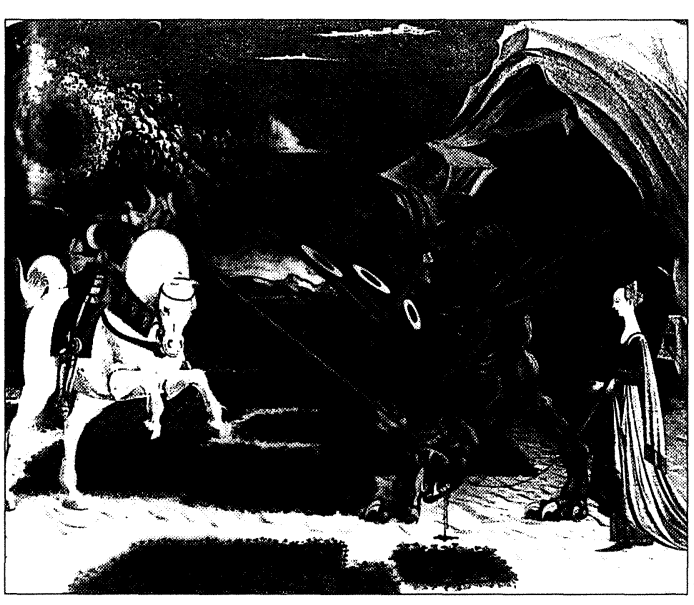

Figura 7.-San Jorge y la doncella. Paolo Ucello. National Gallery. ca de Plutarco, clavaban a las vírgenes en cruces y las arrojaban al río; en Bonny (Oeste de África) en el siglo XIX, cuando la marea estaba baja, ataban unas vírgenes a unos palos de madera para ofrecérselas a los tiburones; en algunas islas del Pacífico las entregaban a los cocodrilos. Todavía en el siglo XX se seguían contando hazañas realizadas por san Jorge en varias zonas de África Occidental: los dagomba sufrían 
de sequía y la única poza existente estaba custodiada por un feroz búfalo, hasta que llegó el héroe y lo mató, cortándole los cuernos (uno de oro y el otro de plata) y el rabo, y luego se casó con la hija del rey, a pesar de que ésta no tenía piernas; entre los koba la fiera era un caballo-antilope con cola de oro; para los fulbe era un monstruo de tres cabezas (Huxley 1994: 15-17).

\section{EN LAS PROCESIONES DEL CORPUS}

Pero la hazaña emprendida contra un dragón que más influencia ha tenido en los rituales festivos, especialmente los del Corpus Christi, se debe a una mujer, santa Marta, hermana de María Magdalena y Lázaro. Tras huir de Palestina y desembarcar en la costa provenzal, le hablaron de un fiero dragón anfibio, que moraba en un bosque cercano al Ródano y que aterrorizaba a la población. Marta lo encontró y lo roció con agua bendita, consiguiendo amansarlo como a un corderito. Este dragón era llamado el tarascón, y a partir de entonces se denominó con tal nombre el lugar, y allí Marta erigió un convento en el que sería enterrada. Los restos de la santa fueron descubiertos en 1187, y pocos años más tarde se consagró una iglesia sobre su tumba (Duchesne 1907:-340). Por aquel entonces la Provenza francesa pertenecía a los catalanes. En Tarascón, a mediados del siglo XV, sacaban por el Corpus un monstruo llamado vieja abuela o tarasca, que poseía una gran joroba escamada erizada de pinchos y una cabeza móvil, manejada por un hombre escondido en su interior. Debió ser tan ingenioso el mecanismo - capaz de atrapar los sombreros de los espectadores incautos- que este artilugio fue imitado en otras ciudades. Consta que ya en 1457 salía en Tortosa una bestia procesional con aspecto de tortuga con cuello extensible, conocida como cuca fera, que todavía hoy día interviene, por lo que es tenido como el ejemplar más antiguo de Europa. Por otro lado, en el ayuntamiento de Zamora se sigue colocando en Corpus una tarasca atravesada por la lanza de santa Marta. He aquí un exponente del anti-mito: la doncella vence al dragón.

En estas procesiones era frecuente que se representara cabalgando sobre el monstruo a una bella joven, alegoría de la fe dominando al demonio, pero también podía representar a la meretriz de Babilonia o a una sensual mujer negra, depositarias de los vicios sexuales (en Toledo encarna a una lujuriosa Ana Bolena, causante de la pérdida de Inglaterra para el catolicismo). Por tanto, la figura de la mujer en este ritual semi-litúrgico era ambivalente, simbolizando, tanto a la Virtud, que vencía al monstruo, como al Vicio, una réplica o alter ego del dragón infernal. Más adelante se la representó como ridícula y presuntuosa damisela, ataviada con las ropas que se suponía iban a constituir la moda femenina. 
Para iluminar su significado inicial, se puede acudir a Galicia. En documentos del siglo XVI se menciona como antiquísima la costumbre de las penlas, a cargo de panaderas y horneras. Estas penlas son niñas ataviadas como ángeles, que se llevan a hombros en la procesión del Corpus, representando la alegría. Un arzobispo de Santiago quiso prohibirlas en 1606 "por ser cosa indecente nociva" (Filgueira 1979: 150). En Redondela (Pontevedra), hasta 1600 se celebraba una batalla entre san Xurxo — san Jorge- y la Coca -el dragón ${ }^{12}$ - permaneciendo hoy día sólo éste, junto con dos penlas sostenidas por mujeres fuertes (las burras) que no paran de bailar delante del Santísimo (Taboada 1972: 71). Estas penlas pueden emparentarse con las mayas o reinas de la primavera, y sería posible establecer una relación entre la mujer montada sobre la tarasca y la doncella rescatada por el caballero, siendo esta doncella una reina primaveral (cy también una maga habitante de las cavernas?). En todo caso, descendiente de arcaicas imágenes míticas, conectadas con la fecundidad.

En la ya citada localidad portuguesa de Penafiel (entonces bajo dominio español), una sentencia judicial de 1639 estipula que para el Corpus: "los herreros harán una figura de san Jorge que será un caballero vestido de armas buenas, con una lanza en la mano [...] sobre su hermoso caballo como

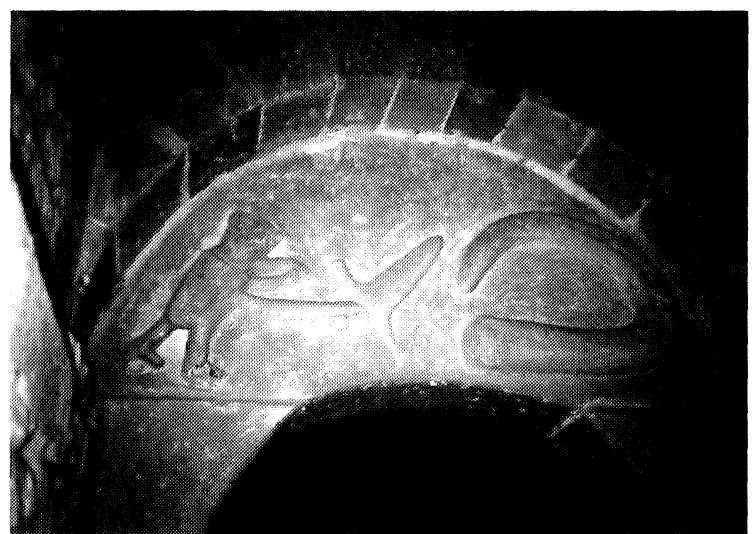

Figura 8.-Lucha del bien y el mal. Tímpano de la Iglesia de San Pelayo, Puentedey (Burgos). siempre fue costumbre, ${ }^{13}$, y se mencionan también la figura de san Miguel, la dama do drago (o de la retorta) y la pella. En la última versión de la danza, san Jorge moría pero era resucitado por el ángel, y en la conclusión decía la reina: "Demos fin ao baile / de Jorge sagrado / Salvem dos gentíos / a dama do drago! $!^{14}$.

El dragón, a pesar de su representación fantás-

${ }^{12}$ En el Corpus de Utrera (Sevilla) de 1574, era san Miguel quien mataba a la tarasca.

${ }^{13}$ Tombo dos festejos de Corpus Chirsti, Archivo Municipal de Penafiel.

${ }^{14}$ A.M.: “Origem das danças nas festas de Corpus-Cristi. Penha-Fidelis 1927: 71. También se dice en este artículo que la imagen de san Jorge fue introducida en las fiestas en 1378 por el rey Juan I, quien "lo invocaba en las batallas en oposición a los españoles que invocaban a Santiago" (p. 69). 
tica, era un ser familiar, ya que todos los pueblos grandes tenían el suyo. Su apariencia era la de un gran saurio acuático. Y tanto su nombre gallego coca como el catalán cucafer, se pueden derivar del cocadriz de la General Historia del rey Alfonso X: el cocodrilo. En el claustro de la catedral de Sevilla cuelga del techo un cocodrilo disecado, que se dice fue capturado en 1260 . Y hay más iglesias que también alojan cuerpos de saurios del río Nilo que pudieron haber servido como modelos del legendario dragón.

Un propagandístico uso de este ser pluri-simbólico se hizo durante el franquismo inicial, cuando la Enciclopedia práctica del párvulo enseñaba la historia como un cuento de hadas, donde el maligno dragón del comunismo fue vencido por ese béroe que era el Caudillo Franco $^{15}$.

A comienzos del siglo XXI, el hábitat del dragón no se reduce aal país de las hadas", como sugiere Tolkien, sino que también se encuentra en ritos festivos semirreligiosos ${ }^{16} \mathrm{y}$ en tan avanzados medios de expresión como el comic, el cine y los anuncios televisivos. Desde King Kong a Godzilla, pasando por el vampiro Drácula, los dinosaurios de Spielberg y los extraterrestres aliens, una cierta similitud de comportamiento permite agruparlos dentro de la misma esfera de acción proppiana. Por ello, debe seguir siendo una imagen común en los sueños, como constató Jung (1995: 41). Los míticos dragones se conservan bien vivos.

\section{EN BUSCA DE INTERPRETACIONES}

Vinculando manifestaciones culturales, podemos elaborar la siguiente cadena de conexiones culturales:

- El mito renace en el cuento (Propp 1974: 386).

- Los mitos y los cuentos son explicaciones del mundo (Bettelheim 1977: 65).

15 "En un país donde todo era felicidad y contento nació un día un dragón de siete cabezas. La fiera fue creciendo y comenzó a sembrar el mal [...] asaltaba haciendas, incendiaba las iglesias, pisoteaba los Crucifijos, insultaba a la Virgen María. Los niños no podían ni rezar ni reir. Y el bello país, antes tan feliz, se tiñó de lágrimas y de sangre. Ese bello país es España. Y el Dragón se llama comunismo [...] Y un día ardiente y caluroso de julio, como llovido del cielo, bajó a la tierra de un pájaro de acero un Héroe valiente y decidido, y salió al encuentro del Dragón con su espada desnuda. Dura fue la lucha del Héroe y el Dragón [...] poco a poco, el Dragón fue perdiendo brazos y cabezas [hasta quedar] muerto para siempre. Y el bello país volvió a ser feliz" (Barcelona: Salvatella, s.f.).

${ }^{16}$ Por Real Cédula de 1780, los festivos dragones, gomias o tarascas fueron prohibidos como herencia supersticiosa. Aunque esta prohibición les asestó un terrible golpe, todavía se pueden encontrar dragones por las calles ibéricas en muchas fiestas del Corpus. 
- El folklore pudo ser parte del rito, y en él se pueden conservar rasgos míticos (Propp 1982: 151).

- Los mitos cambian, las costumbres permanecen, aunque se han olvidado sus razones (Frazer 1981:542).

Aceptando la validez de estas conexiones, se han ido modificando las explicaciones que justifican nuestras costumbres y, tanto los rituales festivos, como los cuentos, siguen sirviendo como vehículos transmisores de los antiguos significados de los mitos que han ido configurando las diversas culturas. Y los símbolos del pasado ofrecen dificultad para su comprensión.

Extrayendo datos etnológicos de éstos y otros autores ${ }^{17}$, y resumiendo los materiales que se han ido aportando, se puede elaborar un cuadro que plasme un modelo estructural del universo cultural de la trama que estamos investigando desde múltiples orientaciones:

A continuación se propondrá un sistema de transformaciones de la situación o función (según Propp) del rapto de la doncella, contemplando las esferas de acción de raptor, raptada y liberador. Por último, se presentarán diversas propuestas interpretativas de este campo semántico.

VARIANTES FORMALES DEL RAPTO DE LA DONCELLA

(histórico-literario-legendario-religioso-mítico-ritual)

\begin{tabular}{|c|c|c|c|c|}
\hline Localizaciōn & Motivo & Raptor & Raptada & Liberador \\
\hline \multicolumn{5}{|l|}{ CULTURA HISPÁNICA } \\
\hline Pueblos españoles, 2003 & fiesta patronal & moros & Virgen María & cristianos \\
\hline León, 2003 & fiesta patronal & moros & ocho doncellas & - \\
\hline Cuenca, hasta 1975 & fiesta patronal & cristianos & reina mora Floripes & - \\
\hline Penafiel, hasta 1930 & fiesta del Corpus & dragón + turcos & dama cristiana & san Jorge \\
\hline Pirineo $(\mathrm{Fr})$, hasta $\mathrm{XX}$ & camaval & oso & oveja & pastor + gitanos \\
\hline$"$ & $"$ & oso & moza Rosetta & domador+cazadores \\
\hline Granada, 1675 & comedia teatral & moriscos rebeldes & María de Solís & general cristiano \\
\hline Málaga, 1673 & comedia teatral & moros & Málaga & cristianos \\
\hline México, 1651 & fiesta universitaria & troyanos & bella Helena & griegos \\
\hline España, antes 1618 & comedia de L. de Vega & moros & cien doncellas & cristianos/as \\
\hline Don Quijote II, 1615 & novela & moros & Melisendra & su esposo D.Gayferos \\
\hline Valencia, 1609 & fiesta beatificación & fieras & dama encantada & caballeros? \\
\hline Lorca, 1571 & alegrías públicas & caballero + salvajes & dama hermosa & caballero de Venus \\
\hline $\begin{array}{c}\text { Binche, } 1549 \\
\text { " }\end{array}$ & $\begin{array}{c}\text { fiestas al heredero } \\
"\end{array}$ & $\begin{array}{l}\text { señor del castillo } \\
\text { salvajes }\end{array}$ & $\begin{array}{l}\text { reina encantada } \\
\text { damas corte }\end{array}$ & $\begin{array}{l}\text { poseedor de la espada } \\
\text { nobles corte }\end{array}$ \\
\hline Valencia, 1538 & fiesta palaciega & turcos & damas & comendadores \\
\hline Barcelona, 1424 & cortejo del Corpus & vibora & doncella & san Jordi \\
\hline Valencia, 1373 & bodas reales & dragón + salvajes & novia & caballeros corte \\
\hline
\end{tabular}

17 Véase mi tesis doctoral, Representaciones bispánicas de conquista. Madrid: Universidad Complutense, 1988. 
DEMETRIO E. BRISSET

\begin{tabular}{|c|c|c|c|c|}
\hline Localización & Motivo & Raptor & Raptada & Liberador \\
\hline Provenza, XII & leyenda & dragón o tarasca & - & santa Marta \\
\hline Norte del Duero & romance & moros & esposa cristiana & - \\
\hline \multicolumn{5}{|l|}{ OTRAS } \\
\hline Universal & cuento & sierpe o dragón & princesa virgen & humilde héroe \\
\hline Irlanda & leyenda & gigante & bella joven & héroe + animales \\
\hline El Cairo, hasta XX & rito agrícola & río & semilla & - \\
\hline Egipto & rito agrícola & río & doncella & - \\
\hline Muy extendido & rito fecundidad & monstruo acuático & doncella & - \\
\hline Fenicia + Cartago & rito religioso & dios del fuego Moloc & niños/as & - \\
\hline Tebas & mito & héroe Hércules & reina de amazonas & - \\
\hline Grecia & poema épico & troyanos & bella Helena & su esposo Menelao \\
\hline Grecia & mito & monstruo acuático & Andrómeda & héroe Perseo \\
\hline Grecia & mito & centauros & mujeres lapitas & guerreros lapitas \\
\hline Atenas & mito & Minotauro & siete mozos/as & héroe Teseo \\
\hline India & epopeya & demonio & Sita & su novio el dios Rama \\
\hline Grecia & mito agrícola & dios del infiemo & doncella Perséfone & - \\
\hline Creta & mito & dios-toro Júpiter & princesa Europa & - \\
\hline India & mito védico & sierpe & sol & dios Indra + caballos \\
\hline Religiones arcaicas & mito religioso & monstruo & aguas & $\operatorname{dios}$ \\
\hline$"$ & $"$ & dios antropomorfo & vida humana & - \\
\hline$"$ & $"$ & dios animal & vida humana & - \\
\hline$"$ & $"$ & difuntos & vida humana & - \\
\hline
\end{tabular}

SISTEMA DE TRANSFORMACIONES:

\begin{tabular}{|c|c|c|}
\hline Raptor & Raptada & Liberador \\
\hline moros & imagen de la Virgen & cristianos \\
\hline extranjeros & $"$ & santos \\
\hline gigante & 1 & nobles \\
\hline salvajes & 1 & caballeros \\
\hline dragón o monstruo & I princesa-doncella & héroes \\
\hline$\infty 0$ & I novia & domador \\
\hline demonio & 1 & dioses \\
\hline río & & dioses \\
\hline
\end{tabular}

\section{INTERPRETACIONES:}

\begin{tabular}{lll}
\multicolumn{1}{c}{ Raptor } & \multicolumn{1}{c}{ Raptada } & \multicolumn{1}{c}{ Liberador } \\
$\begin{array}{ll}\text { Naturológicas: } \\
\text { tierra } \\
\text { muerte }\end{array}$ & $\begin{array}{l}\text { semilla } \\
\text { vida humana }\end{array}$
\end{tabular}

Sicoanalíticas: (y androcéntricas: son fantasmas simbólicos masculinos)

- Según Bettelheim (1977: 159) :

padre viejo la madre yo, el héroe

el ello = naturaleza irracional,

impulsos instintivos,

en conflicto edípico 


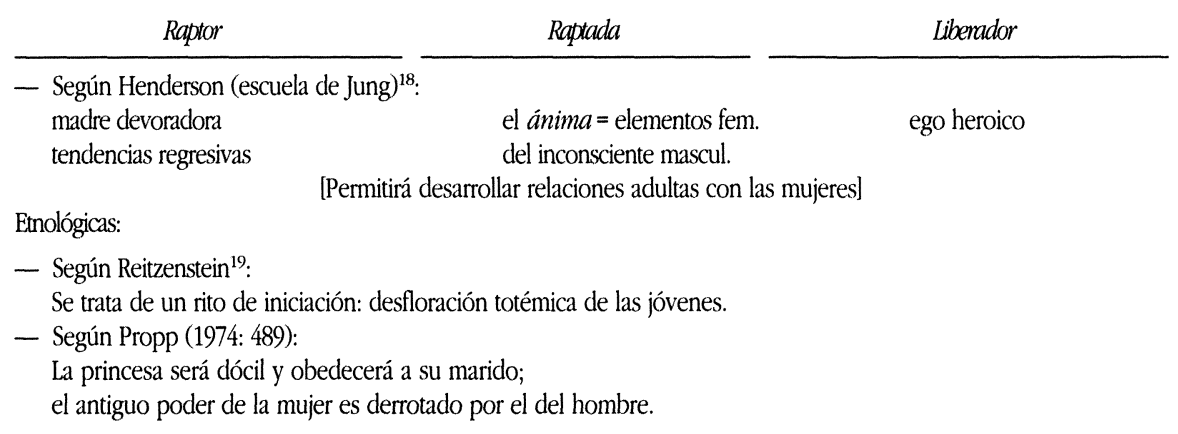

Pero realmente, al dragón le entregan en sacrificio a la doncella, que es traicionada, por lo que podríamos añadir que:

En la sociedad patriarcal, por la superioridad física masculina se arrebata a la mujer la capacidad de decidir por sí misma, justificándolo al negarle simbólicamente, tanto la fertilidad (de la que también se apropian los hombres, exclusivistas del poder), como la potestad de vencer al mal.

\section{BIBLIOGRAFÍA CITADA}

Alenda y Mira, JenARo. 1903. Relaciones de solemnidades y fiestas públicas de España. Madrid: Suc. de Rivadeneyra.

AMADES, JOAN. 1966. Las danzas de moros y cristianos. Valencia: Diputación.

ATHIR, IBN-EL. 1896. Annales du Maghreb et de L'Espagne (S. XIII) (trad. E. Fagnan). Argel.

Bettelheim, Bruno. 1977. Psicoanálisis de los cuentos de hadas. Barcelona: Grijalbo. BRISSET, DEMETRIO. 1988. Representaciones bispánicas de conquista. Madrid: Universidad Complutense.

-. 1997. "Proceso evolutivo de los rituales de conquista en España". RDTP LII: 65-104. BURGUI, FRAY TOMÁs. 1774. San Miguel / de Excelsis / representado / como Príncipe Supremo / de todo el reyno de Dios en Cielo, y Tierra, / y como protector excelso / aparecido, y adorado en el Reyno de Navarra. Pamplona.

18 Ver en JUNG et al. (1995: 118-125).

19 Teoría expresada en 1909 y recogida por Propp, para quien, aún sin ser confirmada por suficientes datos etnológicos, resuelve varios problemas simbólicos. En un "nuevo régimen social, las nuevas formas de matrimonio hacen que los hombres vean en la máscara que lleva a cabo la desfloración no ya a un benefactor, sino a un violador, y se le mata", y también se pueden interpretar varias acciones porque "durante la primera noche [nupciall la mujer es fecundada por un antepasado totémico, y de aquí se deriva también el jus primae noctis: este derecho pasa luego de las manos del más fuerte mágicamente al del más fuerte socialmente, y se convierte en una forma de usurpación de los derechos conyugales" (Propp 1982: 486-489). 
Caro Baroja, Julio. 1974. Ritos y mitos equívocos. Madrid: Istmo.

CARRERES ZACARÉs, SALVADOR. 1925. Ensayo de una bibliografía de libros de fiestas celebradas en Valencia y su antiguo reino. Valencia: H. de Vives Mora.

CHAVES, LuIS. 1948. "O romanceiro e o teatro popular do norte de Douro". Biblos II. Coimbra.

Devoto, Daniel. 1960. "iLa famosa fiesta de Bains!n, en J. Jacquot (ed.), Les fêtes de la Renaissance. París: CNRS, t. II.

DuCHESNE, LOUIS. 1907. Fastes Episcopaux de l'Ancienne Gaule. París.

Filgueira VAlverde, XosÉ. 1979. Adral. Coruña: Ed. do Castro.

FRAZER, JAMES G. 1981. La rama dorada. Madrid: FCE.

GABET, PHILIPPE. 1989. "Santiago Matamoros et ses doublets". Mythologie Française 155: 35. HÉRELLE, G. 1923. "Les mascarades souletines". Revue International des Etudes Basques XIV: 173.

HERÓDOTO. 1983. Los Nueve Libros de la Historia. Barcelona: Orbis.

HuXLEY, FRANCIS. 1994. El dragón. Madrid: Debate.

IsIDORO DE SEVILLA. 1951. Etimologías (versión castellana de Cortés y Góngora, L.). Madrid: BAC.

JunG, CARL G. 1995. El hombre y sus simbolos. Barcelona: Paidós.

LÓPEZ, DAvid G. 1999. León. Fiestas y romerias. León: Diputación Provincial.

MILÁN, LUIS. 1874 [1561]. El Cortesano. Madrid.

PÉREZ DE HITA, GINÉS. 1572. Libro de la poblazión y hazañas de la mui noviissima y leal ciudad de Lorca. Mss. en la BNM.

PÉrez PASTOR, CRISTÓBAl. 1911. "Nuevos datos sobre el histrionismo español", en E. Cotarelo y Mori, Colección de entremeses, loas, bailes, jácaras y mojigangas. Madrid: NBAE.

Propp, WLADIMIR. 1971 [1928]. Morfología del cuento. Madrid: Fundamentos.

—. 1974 [1940]. Las raíces históricas del cuento. Madrid: Fundamentos.

-. 1982 [1934]. Edipo a la luz del folklore. Madrid: Fundamentos.

Relación verdadera, del re/cebimiento, que la muy Noble y muy / ..., Burgos, 1571.

TABOAda Chivite, Xesús. 1972. Etnografia Galega. Vigo: Galaxia.

VAN GENNEP, ARNOLD. 1947. Manuel de folklore français contemporain. París: Picard.

Vega CARPIO, LOPE DE. 1974. Obras escogidas. Madrid: Aguilar.

VorÁgIne, JACOBO DE LA. 1982. Leyenda Áurea. Madrid: Alianza.

WARMAN, ARTURO. 1985. La danza de moros y cristianos. México: INAH. 